\title{
Oral Hygiene Knowledge and Practices among School Age Children: an
}

\section{Assessment Study}

\section{${ }^{1}$ Prof. Dr. Wafaa El-Sayed Ouda, ${ }^{2}$ Dr. Nabila Hassen Abd Ella, ${ }^{3}$ Dr. Nagwa Rizk Mohammed, ${ }^{4}$ Amal Ashour Mahmoud Salim}

\author{
${ }^{1}$ Professor of Pediatric nursing Faculty of Nursing, Ain Shams University \\ ${ }^{2}$ Assis Prof. in Pediatric Nursing Faculty of NursingPort Said University \\ ${ }^{3}$ Lecturer in Pediatric Nursing Faculty of NursingPort Said University \\ ${ }^{4}$ BSc Nursing Faculty of Nursing Suiz Canal University
}

\begin{abstract}
Background: Oral hygiene is the practice of keeping the mouth and teeth clean to prevent dental problems, especially dental caries, gingivitis and bad breath. The purpose of maintaining oral hygiene is to prevent the build-up of plaque. Aim of this study was to assess the oral hygiene knowledge and practices among school age children. The research design was a descriptive. It was carried out at 5 governmental primary schools representing Port-Said City. The study subjects consisted of 202 school age children in the age group of 10-12 years, regardless their gender and residence. The data was collected using an interview questionnaire sheet and observational checklist to assess the study subjects' knowledge and reported practices related to oral hygiene. The results of the study revealed that one third of the studied children were at the age group of 11 years, more than half were females. Moreover, less than half and more than one third of studied children had unsatisfactory total knowledge and reported practices respectively regarding oral hygiene. In addition to more than half of studied children's don`t follow up about their teeth. It was concluded that knowledge and reported practices of the studied children regarding oral hygiene practice was satisfactory by more than half of them. The study recommended raising awareness of school age children about oral health and hygiene through oral health education sessions and community outreach programs in children's school settings.
\end{abstract}

Key words: Oral hygiene, school age children, pediatric nursing, knowledge and reported practice. 


\section{INTRODUCTION}

Oral health plays an important role in the overall health of the body and the quality of life of individuals (Hashemian et al., 2012; Pakpour et al., 2012 and Fallahi et al., 2013). Oral health is a fundamental component of health and well-being. The oral health is a state that contributes positively to one's physical, mental and social well-being by allowing the individual to speak, eat and socialize unhindered by pain, discomfort or embarrassment (Canadian Dental Association, 2015d). This includes being free from oral and facial pain, oral and throat cancer, oral infection, gum disease, tooth decay, tooth loss and other oral-associated diseases (World Health Organization, 2012). Oral hygiene is most important for good health in general. Poor oral hygiene can be a source of many diseases. By maintaining good oral hygiene, the occurrence of many diseases can be prevented. Unfortunately, oral hygiene practice is very low in our society. Dental caries and periodontal problems are due to poor oral hygiene practices (Morenike et al., 2007). Oral hygiene, including twice daily tooth brushing, is critical in preventing gum disease and maintaining good oral health (Hassijaand Sridhar, 2014). Dental caries is a multifactorial, irreversible microbial disease of the calcified tissues of the teeth, characterized by demineralization of the inorganic portion and destruction of the organic substance of the tooth, which often leads to cavitations (Latoo et al., 2009). A large number of schoolaged students in developing countries suffer from tooth decay and have limited access to oral health care services. Dental caries affects $60-90 \%$ of school-age children and most of the adults. Periodontal disease is prevalent in 50-90\% of school age children, and is severe in $10-15 \%$ of them, while gingival diseases occur in the majority of children and adolescents (Al-Mutawa et al., 2011). Oral disease burden is significantly higher among poor and disadvantaged populations with an increase in developing countries. Globally, poor oral hygiene occurring due to increasing plaque and calculus deposits with increasing age has been reported among children and adolescents (Saied-Moallemi et al., 2009 and Mbawalla et al., 2010). A recent publication by Folayan et al. (2012)also showed that the incidence for caries was $9.9 \%$ in a population of primary school children, with a higher incidence in primary teeth than in the permanent dentition. Understanding caries pattern, its epidemiology and how the epidemiologic profile changes over time is important because caries is the primary pathological cause of tooth loss in children in many African countries. Also, an understanding of the caries profile, that is, where new caries emerges, can be useful in proper planning for the utilization of scarce resources. It 
also helps to maximize the potential outcome of resources available for preventive programs, including oral health prevention programs (Ashiwaju et al., 2011). Pediatric nurses are on the front lines of children's health care delivery. They can play an important role in providing oral health screening, early risk assessment and preventive services to children who are at the highest risk for developing early childhood caries. In addition to advising families of proper oral health, fluoride supplementation, prevention of damaging oral health habits and tooth decay and the need for referrals to pediatric dentists for anticipatory guidance (Donna and Donna, 2009).

\section{AIM OF STUDY:}

Assess the oral hygiene knowledge and practices among school age children.

\section{SUBJECTS AND METHODS:}

A descriptive research design was used to conduct the current study at governmental primary schools at Port-Said city which is divided into five sectors. Representative schools were randomly selected from a list of primary schools in Port-Said Directorate of Education for the study purpose. One school from each sector was included namely: Safia Zaghloul, Kasim Amin, Abbas El-Akkad, Omar Ibn El-Khatab and Maka El-Mokarama. The sample for the present study was collected and its size was determined using Kish and Leslie, 1965 formula, $n=P(100-P)^{*} Z^{2} / E^{2}$ where $n$ is the sample size, $\mathrm{Z}$ is a percentile of the standard normal distribution by $95 \%$ confidence level $=1.96$., $\mathrm{P}=$ Prevalence of school age children at Port-Said City $=31.08 \% \mathrm{E}=$ Percentage of standard error. Using this formula, a sample of 202 was obtained to satisfy a predetermined inclusion criteria (age group of 10-12 years regardless their gender and residence area) this included in fourth grade, with exclusion of children with chronic diseases.

Tools of data collection: Data were collected through using two tools:

Tool (I): Structured interview questionnaire for children. Self administration the interview questionnaire was designed by the researcher after reviewing related literature, and was written in simple Arabic language, the questions were open and closed-ended to gather data in relation to:

Part (I): This part was concerned with: a - Characteristics of school age children. It contained 9 questions about children and their parents (student's age, number of siblings, 
rank, living with whom, caregiver of the child, age of parents and their educational level, occupation and monthly income/LE).

b- Assessment of children's teeth condition (number and characteristics) (WHO 2007).

Part (II): It was concerned with the school age children's knowledge related to their oral health and hygiene: it is self-administered questionnaire. It contained 29 questions, (5) about mouth care, (5) about dental decay, (3) about prevention of dental decay, (6) about follow up, (5) about duration of cleaning teeth and (5) about eating.

Tool (II): Observational checklist to assess school age children's reported practices of oral hygiene. It was adopted from Bulletin and Version (2000:2014) and Jelsoft (2011). It included 11 steps. This tool was concerned with assessment of school age children's reported practices such as: using soft toothbrush and toothpaste containing fluoride for dental brushing to clean the upper jaw, wash outer and inner surfaces of teeth, move the brush from the gums and downwards in the upper jaw or upward in the lower jaw and brush teeth for two minutes at least.

Scoring system of children's knowledge: Scoring system for knowledge of the school age children was estimated as follows: 38 questions. A total score of 74 was given for all questions. The school age children's answers were compared with a model key answer, where (2) scores were given for complete correct answers, (1) for incomplete correct answers and (0) for do not know or incorrect answers. The total knowledge were classified as satisfactory more than $50 \%$ and unsatisfactory less than $50 \%$.

Scoring system of reported practices of the school age children was estimated as follows: The total scores of school age children's reported practices were 22 marks for the 11 items of oral hygiene procedure. The school age children's reported practices were classified into done scores for satisfactory and not done score for unsatisfactory. According to the children's total reported practices, their levels of total reported practice were categorized into satisfactory $>60 \%$ and unsatisfactory $<60 \%$.

Validity and Reliability: Tool was reviewed by a panel of five experts in the field of pediatric, the opinions of the experts for each item was recorded on a 2 points scale: relevant or not relevant and clear or not clear. They were requested to express their opinions and comments on the tool and provide any suggestions for any additions or 
omissions of items. Cronbach's alpha coefficient was used to assess the internal consistency of the questionnaire and its value was (0.78).

Administrative and ethical consideration: An official permission was obtained from the directors of the selected primary schools through official letters from the Dean of the Faculty of Nursing, Port-Said University. The school age children's oral consent and their parents was obtained before data collection ensuring complete privacy, confidentially and anonymity. Children were informed about the aim of the study and were ensured that they had the right to withdraw at any time, and that the study was harmless.

Pilot study: A pilot study was carried out on $10 \%$ (20) of the studied children to test applicability, clarity, relevance and feasibility of the study tools and whether it was understandable or not, and to estimate the proper time required to fill each tool. The necessary modifications were done according to the results of the pilot study, then the children involved in the pilot the study were excluded later from the sample size.

Field of work: Data was gathered starting from the $1^{\text {st }}$ ofOctober2014 till the end of March 2015. The researcher was available by rotation 3 days/week in each study setting for data gathering from 9.30 AM to $2 \mathrm{PM}$. The researcher started by presenting self, aim and expected outcomes of the study. Each child was interviewed individually by the researcher using the previously mentioned tools for 15 minutes in the class during break time.

Statistical analysis was performed using the Statistical Package for Social Sciences (SPSS version 16). Chi-square test was used to study the significance of association between variables of the study. "P value" of $\leq 0.05$ was considered as statistically significant. The knowledge was considered satisfactory if it was $50 \%$ or more than it, and unsatisfactory less than $50 \%$. On the other hand reported practices, was categorized into satisfactory $\geq 60 \%$ and unsatisfactory $<60 \%$.

\section{RESULTS :}

The results in table (1): illustrated the characteristics of the studied children. It was clear from this table that more than one third of the studied children $(36.1 \%)$ were aged 11 years, while $34.7 \%$ were aged 10 years, with mean age $10.94 \pm 0.80$ years. In relation to their genders, it was found that more than half of the studied children (56.9\%) were females and $43.1 \%$ were males. The same table showed that $43.6 \%$ of the studied children had one sibling and $32.7 \%$ had two siblings, $45.0 \%$ were ranked as first children 
and $30.7 \%$ were ranked as middle ones. Also, 95.0\% lived with nuclear families and majority of them $81.2 \%$ received care from both parents.

Table (2): Showed that more than half (51.5\%) of the studied children didn't follow up with dentist visits. The causes of dentist visits were due to tooth ache $44.7 \%$ regular follow up $29.8 \%$ and $25.4 \%$ extract tooth. Also; more than three quarters of the studied children $(76.2 \%)$ reported school absence twice a year due to teeth problems.

Table (3): Showed children's nutritional practices that affect their oral hygiene and illustrated that $80.2 \%$ of them reported once /twice intake of sweets daily, $92.1 \%$ reported eating sweets without cleaning teeth, $60.9 \%$ reported intake of carbonated water during meals, $48.0 \%$ reported intake of milk, vegetables, rice and bread and $38.6 \%$ had snacks between meals as fresh fruits.

Table (4): Describe that there are a statistically significant relation was found between children's total knowledge and their total reported practices regarding oral hygiene and there are a positive relation between total knowledge and total practice.

Table (5): Demonstrated relation between total children's knowledge and their females.

Table (6): Illustrate relation between total children's reported practice and their characteristics. It is clear from this table, there are satisfactory of practice and knowledge were significantly higher among females students. 
Table (1): Number and percentage distribution of the studied children according to their characteristics $(n=202)$.

\begin{tabular}{|c|c|c|}
\hline Characteristics of Studied Children & $\begin{array}{c}\text { Number } \\
\text { (No.) }\end{array}$ & $\begin{array}{c}\text { Percentage } \\
(\%)\end{array}$ \\
\hline $\begin{array}{l}\text { Student's age in years: } \\
10- \\
11- \\
12-13\end{array}$ & $\begin{array}{l}70 \\
73 \\
59\end{array}$ & $\begin{array}{l}\mathbf{3 4 . 7} \\
\mathbf{3 6 . 1} \\
29.2\end{array}$ \\
\hline \multicolumn{3}{|c|}{$\overline{\mathbf{x}} \pm$ SD $(10.94 \pm 0.80)$} \\
\hline $\begin{array}{l}\text { Gender: } \\
\text { Female. } \\
\text { Male. }\end{array}$ & $\begin{array}{c}118 \\
84\end{array}$ & $\begin{array}{l}58.4 \\
41.6\end{array}$ \\
\hline $\begin{array}{l}\text { Number of siblings: } \\
\text { None. } \\
\text { One. } \\
\text { Two. } \\
\text { Three or more. }\end{array}$ & $\begin{array}{c}46 \\
88 \\
66 \\
2 \\
\end{array}$ & $\begin{array}{c}22.8 \\
\mathbf{4 3 . 6} \\
\mathbf{3 2 . 7} \\
1.0\end{array}$ \\
\hline $\begin{array}{l}\text { Rank: } \\
\text { The first. } \\
\text { The middle. } \\
\text { The last. }\end{array}$ & $\begin{array}{l}91 \\
62 \\
49\end{array}$ & $\begin{array}{l}\mathbf{4 5 . 0} \\
\mathbf{3 0 . 7} \\
24.3\end{array}$ \\
\hline $\begin{array}{l}\text { Living with: } \\
\text { Nuclear family. } \\
\text { Extended family. }\end{array}$ & $\begin{array}{c}192 \\
10\end{array}$ & $\begin{array}{c}95.0 \\
5.0\end{array}$ \\
\hline $\begin{array}{l}\text { Caregiver of the child: } \\
\text { Both parents. } \\
\text { The father only. } \\
\text { The mother only. } \\
\text { The grandparent. }\end{array}$ & $\begin{array}{c}164 \\
25 \\
11 \\
2 \\
\end{array}$ & $\begin{array}{c}\mathbf{8 1 . 2} \\
12.4 \\
5.4 \\
1.0\end{array}$ \\
\hline
\end{tabular}


Table (2): Frequency distribution of the studied children according to their frequency of dental visits during the last six months and why in addition to school absence due to teeth problems $(n=202)$.

\begin{tabular}{|l|c|c|}
\hline & Number & Percentage \\
\cline { 2 - 3 } Items & (No.) & $(\mathbf{\%})$ \\
\hline Frequency of follow-up visits to dentist: & & \\
Yearly. & 37 & 18.3 \\
Monthly. & 35 & 17.3 \\
Every six months. & 26 & 12.9 \\
Don't follow up. & 104 & $\mathbf{5 1 . 5}$ \\
\hline Visit the dentist during the last six months: & & \\
Yes. & 114 & $\mathbf{5 6 . 4}$ \\
No. & 88 & 43.6 \\
\hline If yes (n=114), why? & & \\
Toothache. & 51 & $\mathbf{4 4 . 7}$ \\
Regular follow-up. & 34 & $\mathbf{2 9 . 8}$ \\
To extract a tooth. & 29 & $\mathbf{2 5 . 4}$ \\
\hline Frequency of school absence due to teeth & & \\
problems/year: & 154 & $\mathbf{7 6 . 2}$ \\
Two times. & 34 & 16.8 \\
Four times. & 14 & 6.9 \\
Six times. & & \\
\hline
\end{tabular}


Table (3): Frequency distribution of the studied children according to their nutritional practices that affect their oral hygiene $(n=202)$.

\begin{tabular}{|c|c|c|}
\hline Nutritional practices about dental care & $\begin{array}{c}\text { Number } \\
\text { (No.) }\end{array}$ & $\begin{array}{r}\text { Percentage } \\
(\%) \\
\end{array}$ \\
\hline $\begin{array}{l}\text { Daily sweets taken: } \\
\text { Once or twice a day. } \\
\text { Twice to five times a day. } \\
\text { Never. }\end{array}$ & $\begin{array}{c}162 \\
22 \\
18\end{array}$ & $\begin{array}{c}\mathbf{8 0 . 2} \\
10.9 \\
8.9\end{array}$ \\
\hline $\begin{array}{l}\text { Eating sweets continuously without cleaning: } \\
\text { Yes. } \\
\text { No. }\end{array}$ & $\begin{array}{c}186 \\
16\end{array}$ & $\begin{array}{c}92.1 \\
7.9\end{array}$ \\
\hline $\begin{array}{l}\text { Kinds of drinks taken between meals daily: } \\
\text { Sweet juices. } \\
\text { Carbonated water. } \\
\text { Tea and coffee with sugar. }\end{array}$ & $\begin{array}{c}123 \\
58 \\
21\end{array}$ & $\begin{array}{l}28.7 \\
60.9 \\
10.4\end{array}$ \\
\hline $\begin{array}{l}\text { Eating important foods for the health of the } \\
\text { teeth: } \\
\text { Milk. } \\
\text { Vegetables. } \\
\text { Rice. } \\
\text { Bread. } \\
\text { All of the above. }\end{array}$ & $\begin{array}{c}60 \\
24 \\
13 \\
8 \\
97\end{array}$ & $\begin{array}{r}29.7 \\
11.9 \\
6.4 \\
4.0 \\
48.0\end{array}$ \\
\hline $\begin{array}{l}\text { Snacks between meals every day: } \\
\text { Fresh fruits. } \\
\text { Chips and carbohydrates. } \\
\text { Chocolates. } \\
\text { Biscuits and cake. }\end{array}$ & $\begin{array}{l}78 \\
63 \\
34 \\
27\end{array}$ & $\begin{array}{l}\mathbf{3 8 . 6} \\
31.2 \\
16.8 \\
13.4\end{array}$ \\
\hline
\end{tabular}


Table (4): Relation between children's total knowledge level and total reported practices regarding oral hygiene $(n=202)$.

\begin{tabular}{|c|c|c|c|c|c|c|c|c|}
\hline \multirow{3}{*}{$\begin{array}{l}\text { Reported } \\
\text { Practice }\end{array}$} & \multicolumn{4}{|c|}{ Total Knowledge Level } & \multirow{2}{*}{\multicolumn{2}{|c|}{ Total }} & \multirow{3}{*}{$X^{2}$} & \multirow{3}{*}{ p-value } \\
\hline & \multicolumn{2}{|c|}{ Satisfactory } & \multicolumn{2}{|c|}{$\begin{array}{c}\text { Unsatisfactor } \\
\mathbf{y}\end{array}$} & & & & \\
\hline & $\begin{array}{c}\mathrm{N}=11 \\
8\end{array}$ & $\%$ & $\mathrm{~N}=84$ & $\%$ & No & $\%$ & & \\
\hline Satisfactory & & & & & & & \multirow{3}{*}{14.79} & \multirow{3}{*}{$.000^{* *}$} \\
\hline $\mathrm{N}=123$ & 85 & 72.0 & 38 & 45.2 & 123 & 60.9 & & \\
\hline $\begin{array}{c}\text { Unsatisfactory } \\
\qquad \begin{array}{c}\text { N=79 }\end{array}\end{array}$ & 33 & 28.0 & 46 & 54.8 & 79 & 39.1 & & \\
\hline
\end{tabular}

$\chi^{2}$ : Chi square test. $\quad *$ Statistically significant at $\mathrm{P}<0.05$ 
Table (5): Relation between children's total knowledge regarding oral hygieneand their females of personal data( $\mathrm{n}=202)$.

\begin{tabular}{|c|c|c|c|c|c|c|c|c|}
\hline \multirow{3}{*}{$\begin{array}{c}\text { Children's } \\
\text { Characteristics }\end{array}$} & \multicolumn{4}{|c|}{ Total Knowledge Level } & \multirow{2}{*}{\multicolumn{2}{|c|}{ Total }} & \multirow{3}{*}{$\mathbf{X}^{2}$} & \multirow{3}{*}{$\begin{array}{c}\text { P- } \\
\text { value }\end{array}$} \\
\hline & \multicolumn{2}{|c|}{ Satisfactory } & \multicolumn{2}{|c|}{$\begin{array}{c}\text { Unsatisfacto } \\
\text { ry } \\
\end{array}$} & & & & \\
\hline & $\begin{array}{c}\text { No.= } \\
118\end{array}$ & $\%$ & $\begin{array}{c}\text { No.= } \\
84\end{array}$ & $\%$ & No. & $\%$ & & \\
\hline $\begin{array}{l}\text { Age in years: } \\
10 \\
11 \\
12\end{array}$ & $\begin{array}{l}36 \\
43 \\
39\end{array}$ & $\begin{array}{l}30.5 \\
\mathbf{3 6 . 4} \\
33.1 \\
\end{array}$ & $\begin{array}{l}34 \\
30 \\
20 \\
\end{array}$ & $\begin{array}{l}\mathbf{4 0 . 5} \\
35.7 \\
23.8 \\
\end{array}$ & $\begin{array}{l}70 \\
73 \\
59 \\
\end{array}$ & $\begin{array}{l}34.7 \\
36.1 \\
29.2 \\
\end{array}$ & $\begin{array}{c}2.8 \\
4\end{array}$ & .241 \\
\hline $\begin{array}{l}\text { Gender: } \\
\text { Female } \\
\text { Male }\end{array}$ & $\begin{array}{l}75 \\
43\end{array}$ & $\begin{array}{l}63.6 \\
36.4\end{array}$ & $\begin{array}{l}43 \\
41\end{array}$ & $\begin{array}{l}51.2 \\
48.8\end{array}$ & $\begin{array}{c}118 \\
84\end{array}$ & $\begin{array}{l}58.4 \\
41.6\end{array}$ & $\begin{array}{c}\mathrm{Mc} \\
\mathrm{Ne} \\
\text { mar } \\
\text { Tes } \\
\mathrm{t}\end{array}$ & $\begin{array}{l}.004 \\
* *\end{array}$ \\
\hline $\begin{array}{l}\text { Number of } \\
\text { siblings: } \\
\text { None. } \\
\text { One. } \\
\text { Two. } \\
\text { Three and more. }\end{array}$ & $\begin{array}{c}27 \\
49 \\
41 \\
1\end{array}$ & $\begin{array}{c}22.9 \\
41.5 \\
34.7 \\
0.8\end{array}$ & $\begin{array}{c}19 \\
39 \\
25 \\
1\end{array}$ & $\begin{array}{c}22.6 \\
46.4 \\
29.8 \\
1.2\end{array}$ & $\begin{array}{c}46 \\
88 \\
66 \\
2\end{array}$ & $\begin{array}{c}22.8 \\
43.6 \\
32.7 \\
1.0\end{array}$ & $\begin{array}{c}.87 \\
2\end{array}$ & .704 \\
\hline $\begin{array}{l}\text { Rank: } \\
\text { The first. } \\
\text { The middle. } \\
\text { The last. }\end{array}$ & $\begin{array}{l}48 \\
43 \\
27\end{array}$ & $\begin{array}{l}\mathbf{4 0 . 7} \\
36.4 \\
22.9\end{array}$ & $\begin{array}{l}43 \\
19 \\
22\end{array}$ & $\begin{array}{l}51.2 \\
22.6 \\
26.2\end{array}$ & $\begin{array}{l}91 \\
62 \\
49\end{array}$ & $\begin{array}{l}45.0 \\
30.7 \\
24.3\end{array}$ & $\begin{array}{c}4.4 \\
7\end{array}$ & .106 \\
\hline $\begin{array}{l}\text { Living with: } \\
\text { Nuclear family. } \\
\text { Extended family. }\end{array}$ & $\begin{array}{c}112 \\
6\end{array}$ & $\begin{array}{c}94.9 \\
5.1\end{array}$ & $\begin{array}{c}80 \\
4\end{array}$ & $\begin{array}{c}95.2 \\
4.8\end{array}$ & $\begin{array}{c}192 \\
10\end{array}$ & $\begin{array}{c}95.0 \\
5.0\end{array}$ & $\begin{array}{c}.01 \\
1\end{array}$ & .917 \\
\hline $\begin{array}{l}\text { Care giver of the } \\
\text { child: } \\
\text { Mother only. } \\
\text { Father only. } \\
\text { Parent. } \\
\text { Grandparent. }\end{array}$ & $\begin{array}{c}8 \\
8 \\
100 \\
2\end{array}$ & $\begin{array}{c}6.8 \\
6.8 \\
\mathbf{8 4 . 7} \\
1.7\end{array}$ & $\begin{array}{c}3 \\
17 \\
64 \\
0\end{array}$ & $\begin{array}{c}3.6 \\
20.2 \\
76.2 \\
0.0\end{array}$ & $\begin{array}{c}11 \\
25 \\
164 \\
2\end{array}$ & $\begin{array}{c}5.4 \\
12.4 \\
81.2 \\
1.0\end{array}$ & $\begin{array}{c}9.9 \\
7\end{array}$ & .019 \\
\hline
\end{tabular}

$\chi^{2}$ : Chi square test.

*Statistically significant at $\mathrm{P}<0.0$ 
Table (6): Relation between children's total reported practices regarding oral hygiene and their characteristics $(n=202)$.

\begin{tabular}{|c|c|c|c|c|c|c|c|c|}
\hline \multirow{3}{*}{$\begin{array}{l}\text { Children's } \\
\text { Characteristics }\end{array}$} & \multicolumn{4}{|c|}{$\begin{array}{l}\text { Total Reported } \\
\text { Practice }\end{array}$} & \multirow{2}{*}{\multicolumn{2}{|c|}{ Total }} & \multirow{3}{*}{$x^{2}$} & \multirow{3}{*}{ p-value } \\
\hline & \multicolumn{2}{|c|}{ Satisfactory } & \multicolumn{2}{|c|}{ Unsatisfactory } & & & & \\
\hline & $\begin{array}{r}\text { No.= } \\
123 \\
\end{array}$ & $\%$ & $\begin{array}{r}\text { No. }= \\
79 \\
\end{array}$ & $\%$ & No. & $\%$ & & \\
\hline $\begin{array}{l}\text { Student's age in years: } \\
10 \\
11 \\
12\end{array}$ & $\begin{array}{l}42 \\
46 \\
35\end{array}$ & $\begin{array}{l}34.1 \\
37.4 \\
28.5\end{array}$ & $\begin{array}{l}28 \\
27 \\
24\end{array}$ & $\begin{array}{l}35.4 \\
34.2 \\
30.4\end{array}$ & $\begin{array}{l}70 \\
73 \\
59\end{array}$ & $\begin{array}{l}43.7 \\
36.1 \\
29.2\end{array}$ & .222 & .895 \\
\hline $\begin{array}{l}\text { Gender: } \\
\text { Female } \\
\text { Male }\end{array}$ & $\begin{array}{l}80 \\
43\end{array}$ & $\begin{array}{l}65.0 \\
35.0\end{array}$ & $\begin{array}{l}43 \\
36\end{array}$ & $\begin{array}{l}54.4 \\
45.6\end{array}$ & $\begin{array}{l}123 \\
79\end{array}$ & $\begin{array}{l}60.9 \\
39.1\end{array}$ & $\begin{array}{c}\text { McNem } \\
\text { ar } \\
\text { Test }\end{array}$ & $001^{* *}$ \\
\hline $\begin{array}{l}\text { Number of siblings: } \\
\text { None. } \\
\text { One. } \\
\text { Two. } \\
\text { Three and more. } \\
\end{array}$ & $\begin{array}{l}25 \\
50 \\
46 \\
2\end{array}$ & $\begin{array}{r}20.3 \\
\mathbf{4 0 . 7} \\
37.4 \\
1.6\end{array}$ & $\begin{array}{l}21 \\
38 \\
20 \\
0\end{array}$ & $\begin{array}{r}26.6 \\
48.1 \\
25.3 \\
\\
0.0\end{array}$ & $\begin{array}{l}46 \\
88 \\
66 \\
2\end{array}$ & $\begin{array}{l}22.8 \\
43.6 \\
32.7 \\
\\
1.0\end{array}$ & 4.874 & .181 \\
\hline $\begin{array}{l}\text { Rank: } \\
\text { The first. } \\
\text { The middle. } \\
\text { The last. } \\
\end{array}$ & $\begin{array}{l}55 \\
42 \\
26\end{array}$ & $\begin{array}{l}\mathbf{4 4 . 7} \\
34.1 \\
21.1\end{array}$ & $\begin{array}{l}36 \\
20 \\
23\end{array}$ & $\begin{array}{l}45.6 \\
25.3 \\
29.1\end{array}$ & $\begin{array}{l}91 \\
62 \\
49\end{array}$ & $\begin{array}{l}45.0 \\
30.7 \\
24.3\end{array}$ & 2.491 & .288 \\
\hline $\begin{array}{l}\text { Living with: } \\
\text { Nuclear family. } \\
\text { Extended family. }\end{array}$ & $\begin{array}{c}115 \\
8\end{array}$ & $\begin{array}{r}93.5 \\
6.5\end{array}$ & $\begin{array}{l}77 \\
2\end{array}$ & $\begin{array}{l}97.5 \\
2.5\end{array}$ & $\begin{array}{l}192 \\
10\end{array}$ & $\begin{array}{l}95.0 \\
5.0\end{array}$ & 1.614 & .204 \\
\hline $\begin{array}{l}\text { Care giver of the child: } \\
\text { The mother only. } \\
\text { The father only. } \\
\text { The parent. } \\
\text { The grandparent. }\end{array}$ & $\begin{array}{c}5 \\
8 \\
109 \\
1\end{array}$ & $\begin{array}{c}4.1 \\
6.5 \\
\\
\mathbf{8 8 . 6} \\
0.8\end{array}$ & $\begin{array}{c}6 \\
17 \\
\\
55 \\
1\end{array}$ & $\begin{array}{c}7.6 \\
21.5 \\
\\
69.6 \\
1.3\end{array}$ & $\begin{array}{c}11 \\
25 \\
\\
164 \\
2\end{array}$ & $\begin{array}{c}5.4 \\
12.4 \\
\\
81.2 \\
1.0\end{array}$ & 12.10 & .007 \\
\hline
\end{tabular}




\section{DISCUSSION:}

The present study revealed that more than one third of the studied children aged were 11 years, while $34.7 \%$ were aged 10 years, the mean age $10.94 \pm 0.80$ years and more than half of the studied children were females. This finding was in an agreement with (American Academy of Pediatric Dentistry (2009) who found that the fifty percent of students aged were between 10-12 years of age, the mean age of student's was 10 years, and their achievement were average, while two third of them were females.

The present study revealed that the causes of dentist visits were due to toothache, regular follow up and to extract a tooth. This finding was in an agreement with Yusuf and Booyen, (2011) who found that the majority of the participants visited dental clinics only when they had dental pain. This similarity of findings could have been due to that pain was the main reason for visiting the dentist. However, there were those who still visited dentists for dental checkups, fear of injections and fear of tooth loss, while the main reason for the students not visiting dentists was lack of money.

The present study indicated that more than three quarters of the studied children reported school absence twice a year due to teeth problem. This findings in this study were attributed to the fact that if the child doesn't maintain adequate health, the benefits of education will be lost because of absenteeism or lack of attention due to ill health (Minor and Sivakumar, 2011 and Zahra, 2010).

The study revealed that the majority of the studied children eaten sweets continuously without cleaning teeth. This was in an agreement with Dhar et al., (2007) who found that the high prevalence, and consequently uptake of candy, sweetened beverages in urban areas and refined sugar in the form of sweets, biscuits and chocolates, might be raising levels of caries which are said to be associated with changes in standards of living, dietary habits, and increases in sugar consumption. This might be due to dental caries increasing over time and lack of attention of parents.

The present study indicated that there are a positive relation between total knowledge and total practice. This finding was in agreement with Shenoy and Sequeira (2013)who found that higher oral care knowledge, practice and better behavior were resulted on oral health. Because of multiple sources of knowledge from parents, school nurse, friends, computers and the media. 
The study revealed that there are satisfactory of knowledge was statistically higher among females. This finding was in no agreement with Cheah et al., (2010) who found a no significant gender relation was noted in this respect, though certain international studies have reported a higher consumption of sweets amongst the female gender. This might be due to awareness of parents and concept of females about importance of oral health.

\section{CONCLUSION:}

Based on the findings of the current study, it can be concluded that the school age children of the present study had satisfactory knowledge and reported practice regarding oral hygiene with a statistically significant relation between children's females.

\section{RECOMMENDATIONS:}

Raising awareness about oral health and hygiene practices through health education programs and community outreach programs in both public and private school settings over the country for school age children, school teachers and care providers of school age children.

\section{REFERENCES:}

Al-Mutawa, S., Shyama, M., Al-DuwairiandSoparkar, P. (2011): Oral hygiene status of Kuwaiti school children. Eastern Mediterranean Health Journal, 17: 387-91

American Academy of Pediatric Dentistry, (2009): Council on clinical affairs. Policy on vending machines in schools.Pediatr. Dent., 30(7):49-50. http://www.aapd.org/ media/Policies_Guidelines/P_Vending Machines.

Ashiwaju, M., Folayan, M., Sote, E. and Isikwe, M. (2011): Pattern of tooth extraction in children attending tertiary health care centres in Nigeria: A prospective study. $\mathrm{J}$ Clin Pediatric Dent; 36:107-10.

Bulletin, Version 3.8.1. (2000 : 2014): Jelsoft Enterprises Ltd. SearchEngine Optimization by VBSEO @2011, Crawlability, Inc. 
Canadian Dental Association, (2015): Flossing \& Brushing. Retrieved from: http://www.cda- adc.ca/en/ oral_health/cfyt/dental_care/flossing_brushing.asp.

Cheah, W., Tay, S., Chai, S., Bong, C., Luqmanul, H. and Zhuleikha, B. (2010): Oral health knowledge, attitude andpractice among secondary school students in Kuching, SarawakArchives of Orofacial Sciences; 5(1): 9-16

Dhar, V., Jain, A., Van, Dyke, T. and Kohli, A. (2007): Prevalence ofdental caries and treatment needs in school going children of ruralareas in Udaipur district. J Indian Soc PedoPrev Dent. September:119-121.

Donna, H. and Donna,S. (2009): Role of pediatric nurse practitioners in oral health care. Academic Pediatrics, 9:462-6.

Fallahi, A., Ghofranipour, F., Ahmadi, F., Malekafzali, B. and Hajizadeh, E. (2013): Adolescent's perspectives on the factors that influence caries development: A qualitative study. Scientific Journalof School of Public Health and Institute of Public Health Research;10(4): 65-80.

Folayan, M., Sofola, O. and Oginni, A. (2012): Caries incidence in a cohort of primary school students in Lagos State, Nigeria followed up over a 3 years period. Eur Arch Paediatr Dent;13:312-8.

Hashemian, M., Falahi, A., Tavakoli, G., Zarezadeh, Y., Babaki, B. and Rahaei, Z. (2012): Study of the impact of education on inter- dental cleaning behavior based on trans- theoretical model. Journal of Oral Health \& Prevention Dentistry; $1: 37-46$.

Hassija, J. and Sridhar, N. (2014): Healthy lifestyle for healthy gums. Dentistry, 4, doi:10. 4172/2161-1122. 1000235.

Kish, Leslie, (1965): Survey Sampling New York; John Wiley and Sons, Inc. 
Latoo, S., Shah, A., Suhail, M., Qadir,S. and Ahmed, A. (2009): Dental caries. An overview http://www.articlesbase.com/medicine-articles/ dental-caries 1304303.html

Mbawalla, H., Masalu, J. and Åstrøm, A. (2010): Socio demographic and behavioural correlates of oral hygiene status and oral health related quality of life, the Limpopo - Arusha school health project (LASH): A cross-sectional study. BMC Pediatric; 10: 1-10.

Minor, B. and Sivakumar, N. (2011): Oral hygiene status of $7-12$ yearold school children in rural and urban population of Nellore DistrictJournal of the Indian association of public health dentistry. ISSUE:18 SUPPL. III

Morenike, Folayan, Ayomide, Sowole, Aderonke and Kola-Jebutu.(2007):Risk factors for caries in children from South-western Nigeria. Journal of Clinical Pediatric Dentistry; 32: 171-175.

Pakpour, A., Hidarnia, A., Hajizadeh, E., Kumar, S. and Fridlund, B. (2012): Why Iranian adolescents do not brush their teeth: a qualitative study. Int $\mathrm{J}$ Dent Hygiene; 10(2): 86-90.

Saied-Moallemi, Z. (2009): School-based intervention to promote preadolescents' gingival health: A community trial oral health promotion in preadolescents. Community Dentistry and Oral Epidemiology ; 37: 518-26.

Shenoy, R. and Sequeira, P. (2013): Effectiveness of a school dental education program in improving oral health knowledge and oral hygiene practice and status of 12-to 13-year-old school children. Indian J Dent Res [cited 2013 Oct 25];21:253-9.

World Health Organization (2007): Oral health country /Area profile programme. Method of assessing dental caries. Available from: http://www.Whocollab.od.mah.se /expl /orsurvey.html accessed 20 Aug.

World Health Organization (2012): Oral Health. Fact sheet no 318. April Available at: www.who.int/mediacentre/factsheets/fs318/en/index.htmaccessed 19 November 
Yusuf, A. and Booyen, S. (2011): Principle motive of tooth brushing. PubMed Journal May, 66(4): 174-8

Zahra, S. (2010): Oral health among Iranian preadolescents: A school -based health education intervention. Helsinki, Finland: University of Helsinki, Faculty of Medicine.

معلومات وممارسات العناية الصحية للفم بين الأطفال في سن المدرسة:دراسة تقييميه

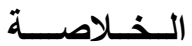

نظافة الفم هي ممارسة للحفاظ علي الفم والأسنان نظيفة لمنع مشاكل الأسنان، ومن أهم هذه المشاكل تسوس

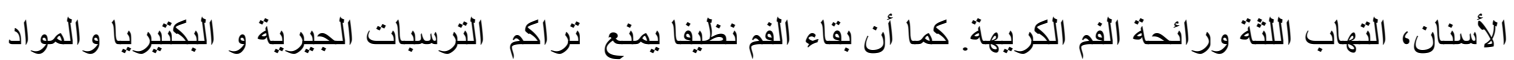
الغذائية على الأسنان بشكل دائم ـ وكان الهدف من الدراسة تقييم ممارسات العناية الصحية للفم بين الأطفال في سن المدرسة. أجريت هذه الدراسة الوصفية في 5 من المدارس الابتدائية الحكومية في مدينة بورسعيد، حيث تضمنت الدر اسة 202 طفلا من الجنسين في عمر 10-12 سنة وقد نم جمع البيانات باستخدام استمارة استبيان لقياس معلومات وممارسات الأطفال عن صحة الفم والأسنان. ومن أهم نتائج الدر اسة أن ثلث الأطفال كانو ا في الفئة العمرية 11سنة، وأكثر من نصفهم كانو ا من الإناث. علاوة علي ذلك أن أكثر من نصف الأطفال لديهم معرفة وممارسات عن صحة الفم. و الخلاصة إن مستوي المعرفة والممارسات للأطفال الخاصة بصحة الفم والأسنان كانت بسيطة ومرضية وقد أوصت هذه الدراسة بضرورة تقديم برنامج تدريبي لطلاب المدارس الابتدائية وذلك من اجل الارتقاء بمعلوماتهم و أدائهم عن صحة الفم والأسنان مما سينعكس بصورة ايجابية علي صحة أسنان الأطفال الكلمات المرشدة: العناية بالفم، الأطفال في عمر المدرسة، ممرضه الأطفال، الممارسات، المعلومات. 